\title{
ICT Adaptation in ERL-based Learning During the COVID-19 Pandemic
}

\author{
Mariyudi $^{1 *}$, Halimatus Sakdiah ${ }^{2}$, Teuku Fadhla $^{3}$, Ikramuddin $^{4}$ \\ ${ }^{I}$ Department of Management, Faculty of Economics and Business, Universitas Malikussaleh, Aceh, Indonesia \\ ${ }^{2}$ Department of Physics Education, Faculty of Engineering, Universitas Malikussaleh, Aceh, Indonesia \\ ${ }^{3}$ Department of Agribusiness, Faculty of Agriculture, University of Abulyatama, Aceh, Indonesia \\ ${ }^{4}$ Department of Management, Faculty of Economics and Business, Universitas Malikussaleh, Aceh, Indonesia \\ *Corresponding author E-mail: mariyudi@ unimal.ac.id
}

Manuscript received 15 April 2021; revised 1 May 2021; accepted 15 June 2021. Date of publication 3 July 2021

\section{Abstract}

The purpose of this study is to produce a learning strategy formulation through ICT media based on Emergency Remote Learning (ERL) in an effort to strengthen post-pandemic learning and support the Merdeka Belajar program. This study uses a theoretical and methodological research approach, which mostly uses a deductive theoretical and qualitative methodological approach, including the SWOT matrix analysis. The structural questionnaire link was designed using a 'Google form' which was sent to 500 high school students and teachers. The test results show that the level of student satisfaction in ICT Adaptation on ERL Based Learning obtained that students are satisfied with the ICT Adaptation on ERL Based Learning experience and no serious obstacles were found during the teaching-learning process during the COVID-19 pandemic except for inadequate interaction between students and teachers, as well as social interaction between students. Alternative strategies in the ICT adaptation on ERL-Based learning formulated using a SWOT matrix analysis approach have been presented with the hope that policymakers feel more confident in their decision-making.

Keywords: ICT Adaptation, ERL-based Learning, COVID-19, SWOT Matrix

\section{Introduction}

The governments in various countries have transformed by launching emergency policy initiatives in the form of suspension of learning and closure of education centers due to the threat of the coronavirus (COVID-19) pandemic. This step was followed by continuing telematics from home teaching activities and the use of information and communication technology (ICT) to stop the increase in the number of COVID-19 infections [1].

Data released by the Center for Systems Science and Engineering (CSSE) on May 1, 2021, shows that there are more than 181 million cases of COVID-19 in more than 222 countries with more than 3,925,285 deaths and more than 165 million recovered cases [2]. By continent, Europe was at the highest level with 47,701,433 cases and 1,097,552 deaths, North America with 40,489,257 cases and 915,905 deaths, followed by Asia with 55,159,009 cases and 780,215 deaths, and South America with 32,368,095 cases and 989,751 deaths [3].

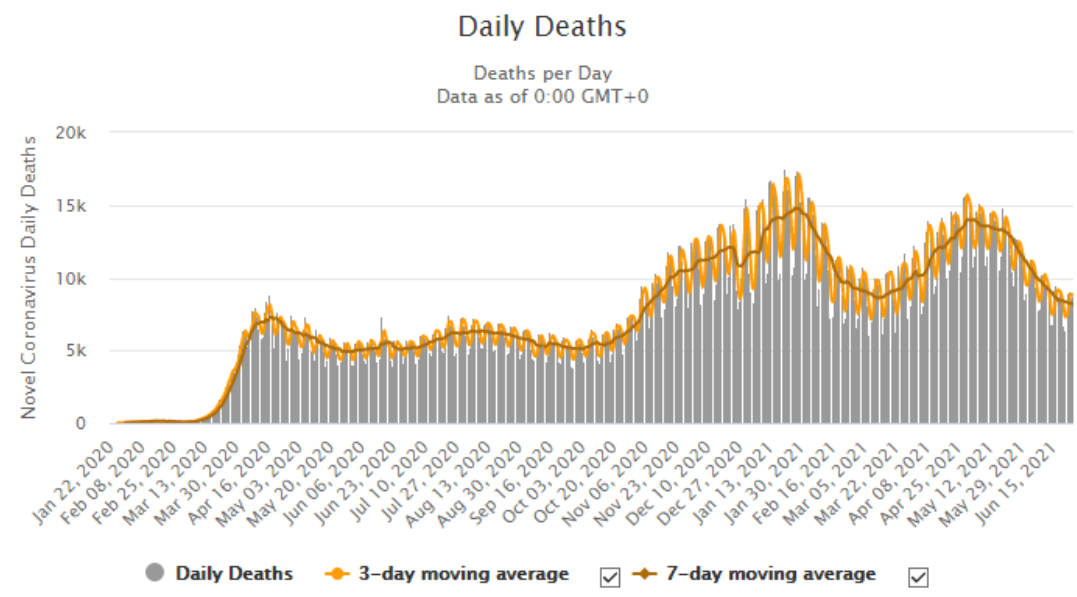

Fig 1. Death rate due to corona virus COVID-19 
Official data on the spread of COVID-19 in Indonesia as of June 25, 2021, showed that there were 2,072,867 positive cases with 56,371 (2.7\%) deaths, and 1,835,061 patients recover (88.5\%). And Aceh Province ranks 20 out of 34 provinces in Indonesia with 3,594 positive cases and 745 people died (covid19.go.id). The dataset is clear that the virus COVID-19 still exist, are very dangerous, and continues to mutate in different variants [4].

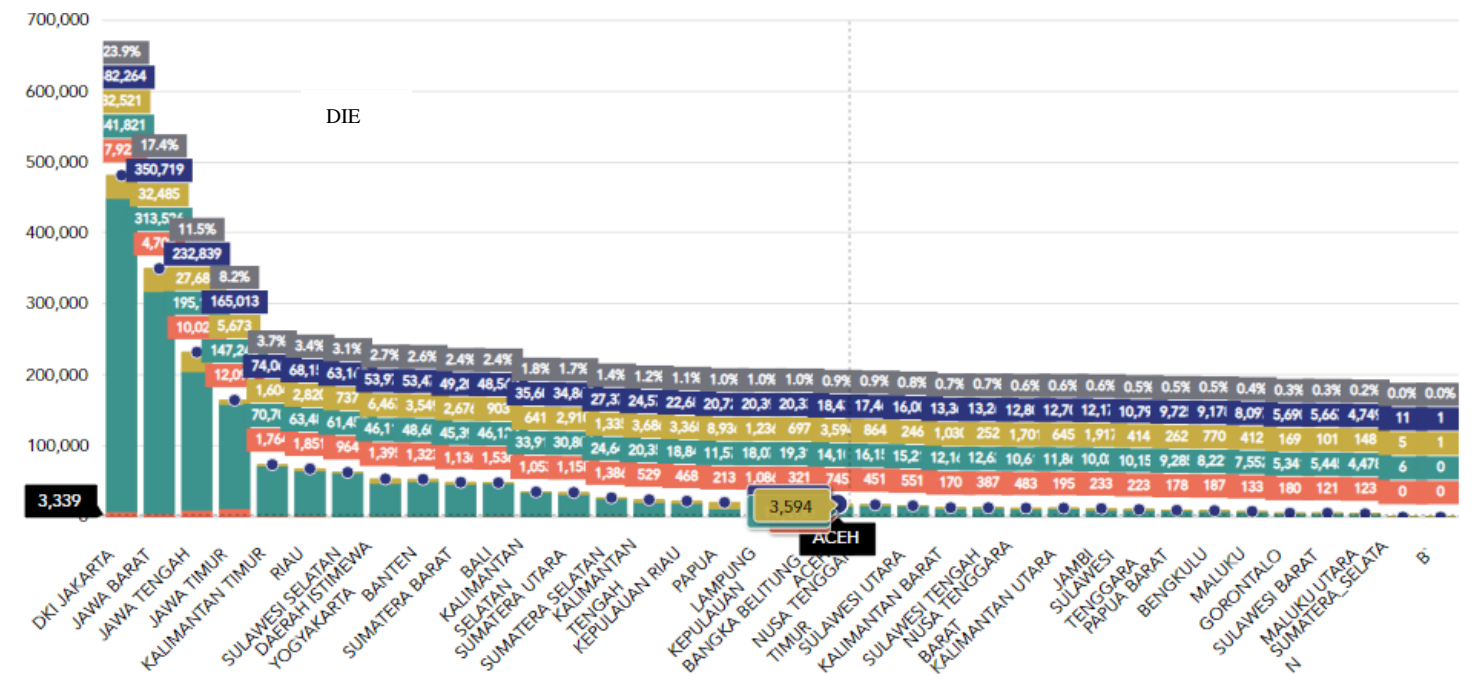

Fig 2. The spread of COVID-19 in Indonesia

UNESCO data of 3 May 2020 shows that at least 1.2 billion youth and students in the world have been affected by the closure of universities and schools due to the outbreak of the COVID-19 pandemic [4][5]. The consequences of school closures for children in confinement can be psychological effects, lack of physical exercise, difficulty in accessing nutrition, and social isolation [4][10] and changes in the education system [11] which result in "Emergency Remote Learning" (ERL) [12] in the form of modified curriculum design, forcing the direct transfer of knowledge through online media without time limit and to adapt it to online modalities [9].

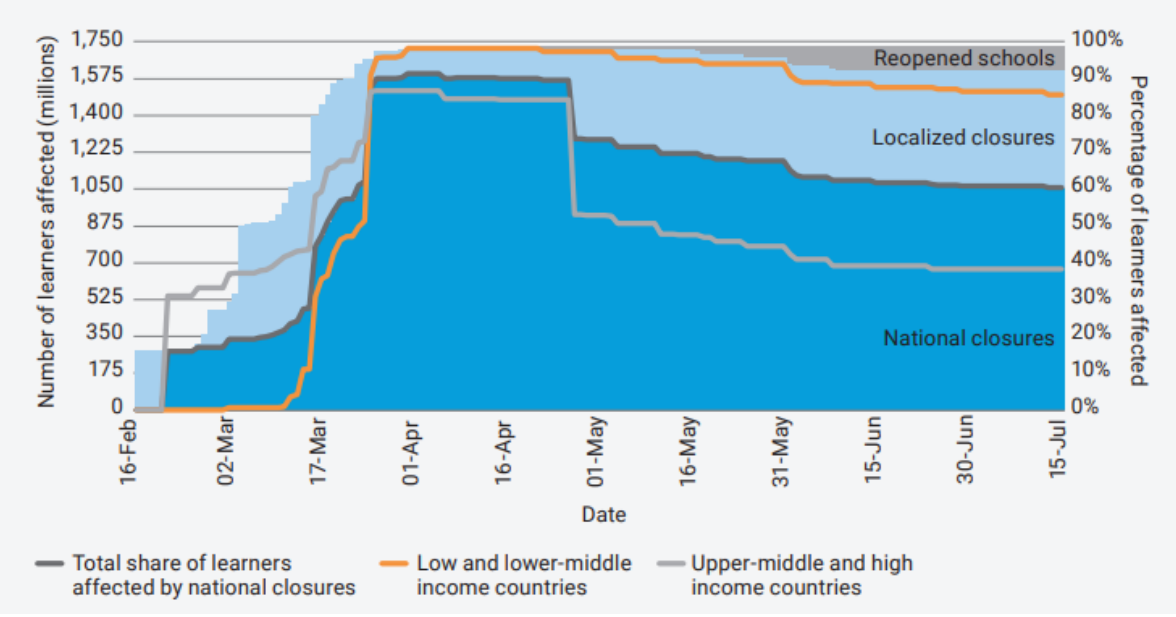

Fig 3. Number of students affected by school closures globally

Teaching activities that suddenly turned into online learning cause various problems and the digital divide in media utilization of ICT [13], such as the availability of resources, gaps in teachers' skills, the gap of use, the access gap, and the adaptation of the online platform in the teaching process $[11,14]$.

Emergency Remote Learning (ERL) or also known as Emergency Remote Teaching (ERT) is a temporary transition of teaching delivery to alternative delivery modes due to an emergency and not planned from the beginning such as online learning [11], which can result in the emergence of Zoombies (people who zoom in a lot) [11], stress, lack of participant involvement, burnout, etc. [14][15][16].

The novel approaches of this research include the contribution of ICT media literacy as a key strategy and applying it effectively in Emergency Remote Learning (ERL)-based learning during the COVID-19 Pandemic. The purpose of this study is to produce a learning strategy formulation through ICT media based on Emergency Remote Learning (ERL) in an effort to strengthen post-pandemic learning and support the Merdeka Belajar program.

\section{Method}

This study uses a theoretical and methodological research approach [17], which mostly uses a deductive theoretical and qualitative methodological approach [18]. The structural questionnaire link was designed using a 'Google form' which was sent to high school students and teachers via e-mail and WhatsApp. A total of five hundred respondents gave complete answers to the questionnaire that was circulated. 
The authors assigned these themes to either strengths, weaknesses, opportunities, or threats for the purpose of SWOT analysis, an analytical approach commonly used to inform strategic planning and decision making [19][20]. The main questionnaire consisted of 17 items, including 7 items regarding the demographic characteristics of the respondents (Table 1).

Table 1. Survey Constructs, Survey Questions and Survey Sources

\begin{tabular}{|c|c|c|c|}
\hline No & Construct & Question & Source \\
\hline 1 & Demographic Characteristic & $\begin{array}{l}\text { 1. Gender } \\
\text { 2. Current class } \\
\text { 3. Family annual income } \\
\text { 4. Ethnicity } \\
\text { 5. Choice of study mode } \\
\text { 6. ICT tools/devices used } \\
\text { 7. Place to Learn }\end{array}$ & SurveyMonkey \\
\hline 2 & $\begin{array}{c}\text { Benefits/challenges/barriers of ERL } \\
\text { learning }\end{array}$ & $\begin{array}{l}\text { 1. Convenience in learning } \\
\text { 2. Access to information and learning materials } \\
\text { 3. Opportunity to interact with teachers } \\
\text { 4. Opportunity to interact with classmates } \\
\text { 5. Learning barriers with ERL mode } \\
\text { 6. Opportunity to study with other classmates } \\
\text { 7. Opportunity to discuss with the teacher } \\
\text { 8. Opportunity to build peer support } \\
\text { 9. Confident to handle difficult tasks with ERL mode } \\
\text { 10. Difficulty applying the concepts taught in the subject }\end{array}$ & {$[21]$} \\
\hline 3 & $\begin{array}{l}\text { Formulation of learning strategies } \\
\text { through the ideal ICT media during } \\
\text { ERL-based learning }\end{array}$ & $\begin{array}{l}\text { 1. IFAS (Internal Factor Analysis Strategic) Matrix: } \\
\text { a. Strengths } \\
\text { b. Weaknesses } \\
\text { 2. EFAS (External Factor Analysis Strategic) Matrix: } \\
\text { a. Opportunities } \\
\text { b. Threats }\end{array}$ & {$[19][20]$} \\
\hline
\end{tabular}

In this research study, the main sampling frame consisted of 1,742,873 students from a total of 532 Senior High Schools in Aceh Province obtained from the Basic Education Data database (dapo.kemdikbud.go.id, 2021), by following special procedures [22][23] to avoid possible errors [24]. A total of 500 samples were grouped by school size [25][26]. Data were analyzed using the statistical software program SPSS 25.0 to obtain descriptive statistical analysis [27][28][29][30].

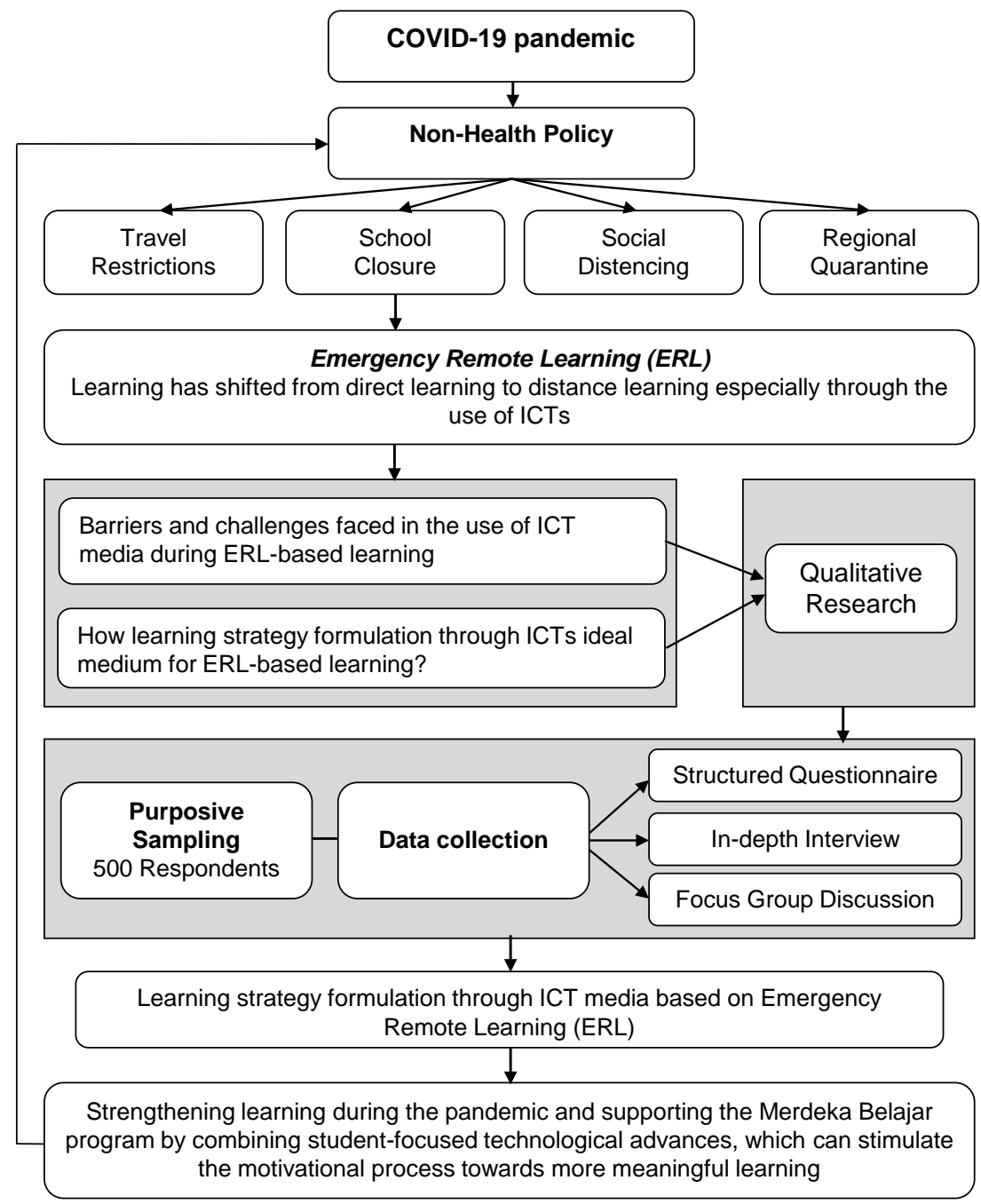

Fig 3. Research framework. 


\section{Result and Discussion}

\subsection{Result}

Information about the characteristics of the respondents in this study is presented in Table 2 which shows the results that the majority of respondents are male (74.4\%), class XI students (55\%), with total family annual income before tax in the range of IDR 4,000,001 - IDR 5,000,000 (52.4\% ). Meanwhile, the Acehnese (61.8\%) and the Batak (19\%) are the majority of the sample of this study. In terms of the chosen learning mode, almost half of the respondents chose remote learning $(49.2 \%)$ and hybrid learning $(45.8 \%)$. The majority of students use laptop computers (47.4\%) and smartphones (39.4\%), and all respondents prefer to learn at school with friends (63\%) and the rest prefer to learn at home $(37 \%)$.

Table 2. Survey Constructs, Survey Questions and Survey Sources

\begin{tabular}{|c|c|c|c|}
\hline Measure & Item & Count & Percentage \\
\hline \multirow{2}{*}{ Gender } & Male & 352 & $70.40 \%$ \\
\hline & Female & 148 & $29.60 \%$ \\
\hline \multirow{3}{*}{ Current Class } & $\mathrm{X}$ & 127 & $25.40 \%$ \\
\hline & XI & 275 & $55.00 \%$ \\
\hline & XII & 98 & $19.60 \%$ \\
\hline \multirow{5}{*}{ Total Family annual income (before taxes) } & $\leq$ IDR $1,000,000$ & 0 & $0.00 \%$ \\
\hline & IDR1,000,001 - IDR 2,500,000 & 0 & $0.00 \%$ \\
\hline & IDR 2,500,001 - IDR 4,000,000 & 145 & $29.00 \%$ \\
\hline & IDR 4,000,001 - IDR 5,000,000 & 262 & $52.40 \%$ \\
\hline & > IDR 5,000,000 & 93 & $18.60 \%$ \\
\hline \multirow{4}{*}{ Ethnicity } & Aceh & 309 & $61.80 \%$ \\
\hline & Gayo & 57 & $11.40 \%$ \\
\hline & Java & 39 & $7.80 \%$ \\
\hline & Batak & 95 & $19.00 \%$ \\
\hline \multirow{3}{*}{ Choice of study mode } & Remote & 246 & $49.20 \%$ \\
\hline & In-person & 25 & $5.00 \%$ \\
\hline & hybrid & 229 & $45.80 \%$ \\
\hline \multirow{4}{*}{ ICT tools/Devices used } & Desktop & 58 & $11.60 \%$ \\
\hline & Smartphone & 197 & $39.40 \%$ \\
\hline & Laptop & 237 & $47.40 \%$ \\
\hline & Tablet & 8 & $1.60 \%$ \\
\hline \multirow{3}{*}{ Place to Learn } & Home & 185 & $37.00 \%$ \\
\hline & On School & 315 & $63.00 \%$ \\
\hline & Off School & 0 & $0.00 \%$ \\
\hline
\end{tabular}

\subsubsection{Student experience in ERL-based learning}

The test results show that the level of student satisfaction in ERL learning obtained the average score of the four questions were in high level (3.52 on the 5-Likert scale) which means that students are satisfied with the ERL learning experience. Where convenience in learning is at a high level (4.75 on the 5-Likert scale), access to information and learning materials were at a high level (4.81 on the 5Likert scale), opportunities to interact with teachers are at a low level (2.36 on the 5-Likert scale), and the opportunity to interact with classmates were in very low level (2.15 on the 5-Likert scale).

\subsubsection{ERL-based learning hindrance}

The challenges of ERL learning faced by students show that the majority of students feel inadequate opportunity to study with other classmates $(78.6 \%)$, inadequate opportunity to establish peer support (71.4\%), difficulty to apply concepts taught in the subject (58\%), inadequate opportunity to discuss with teachers (43.6\%), and Not confident enough to handle difficult tasks with ERL mode (18.4\%).

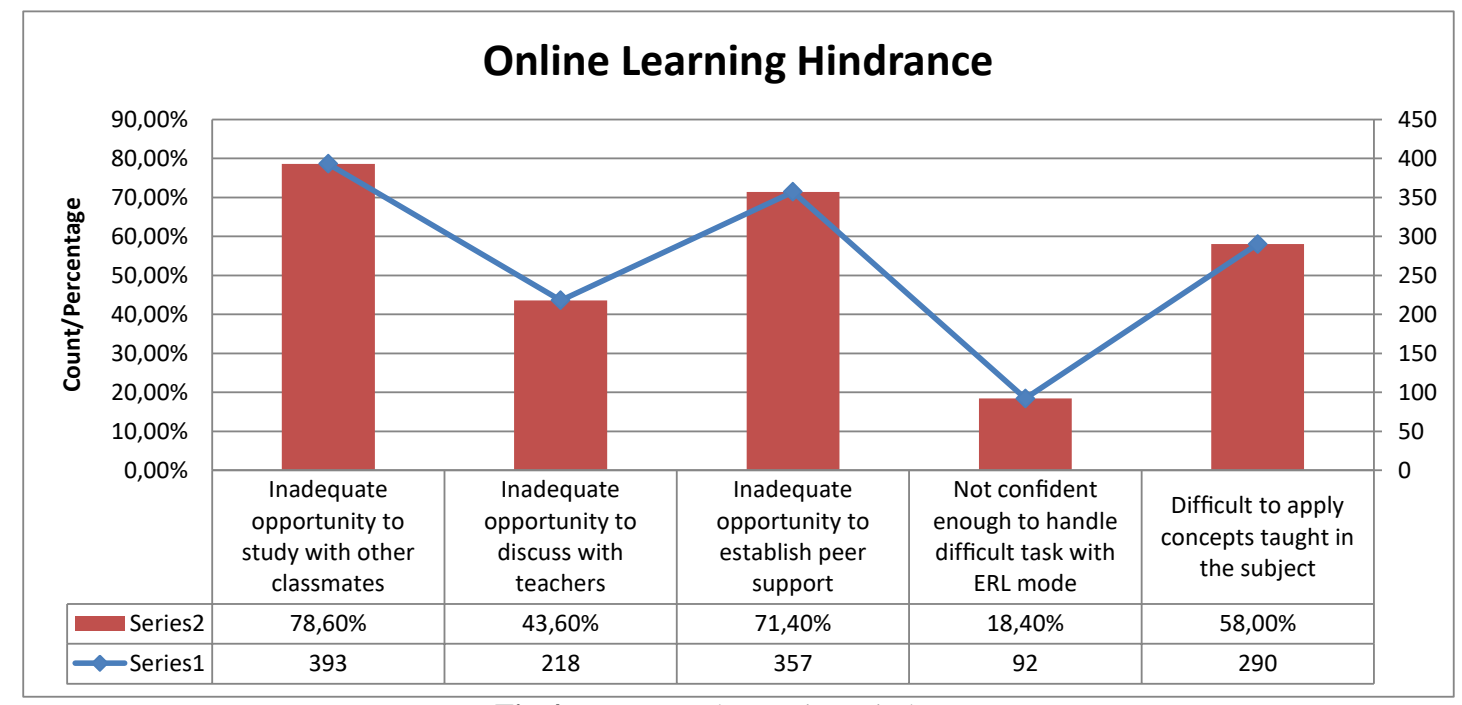

Fig 4. ERL-Based Learning Hindrance 


\subsubsection{Opportunity}

The results of the study also show that although there are serious problems with the curriculum, Emergency Remote Learning (ERL)based learning during the Covid-19 pandemic has provided many opportunities for schools, including opportunities to develop new ICTbased resources, opportunities for online collaboration between academic colleagues, gain new insights and inspiration from others, the importance of working from home and future remote work opportunities. The school also identified skills enhancement opportunities in the use of new technologies, incorporation of hybrid learning in future curriculum development, development of alternative exam methods, and free access to online resources.

\subsubsection{Strengths}

The analysis of strengths highlights the elements of strength possessed by school organizations that can have a positive influence on the use of ICT media in Emergency Remote Learning (ERL)-based learning during the Covid-19 pandemic, including the ability of schools to use digital platforms, the presence of new resources developed by the school include the ability to create unique learning videos, virtual learning, formative quizzes, and the creation of virtual learning environments. There is also free access to high-quality ICT resources from the government. Strengths that are also found in schools are increased skills in new ICT resources, increased awareness and confidence of teachers in online teaching methods and their use, teachers have the potential to transform online learning into all aspects of the curriculum, and are encouraged by free licenses.

\subsubsection{Weaknesses}

The adaptation of ICT media in Emergency Remote Learning (ERL)-based learning during the Covid-19 pandemic still has various weaknesses, including more time needed to learn how to use technology effectively, pressure to produce high-quality resources, additional pressure to fulfill academic assignments others in a limited period of time, teacher-made videos did not result in measurable improvements in student achievement, lack of practical sessions and discussion of teaching materials, loss of social relationship-based teaching, decreased student competency development, teachers did not understand online assessments, and there was no constructive alignment between assignments assessment with learning outcomes.

\subsubsection{ICT Adaptation Learning Strategy in the SWOT Matrix}

The formulation of learning strategies through ICT media based on Emergency Remote Learning (ERL) during the COVID-19 pandemic was carried out using the SWOT matrix. This strategy was formulated based on research analysis in accordance with learning conditions during the COVID-19 pandemic. This strategy focuses on utilizing all existing strengths and opportunities, and at the same time paying attention to the weaknesses and challenges faced in learning programs during the COVID-19 pandemic.

Table 3: ICT Adaptation Learning Strategy in the SWOT Matrix

\begin{tabular}{|c|c|c|}
\hline $\begin{array}{l}\text { Internal/ } \\
\text { External }\end{array}$ & $\begin{array}{l}\text { Strengths (S) } \\
\text { 1. The ability to use digital platforms } \\
\text { 2. The presence of new resources } \\
\text { 3. Virtual learning environments } \\
\text { 4. Free access to high-quality ICT } \\
\text { 5. Skills in new ICT resources } \\
\text { 6. Teachers Awareness and confidence } \\
\text { 7. Transform the curriculum } \\
\text { 8. Encouraged by free licenses }\end{array}$ & $\begin{array}{c}\text { Weaknesses (W) } \\
\text { 1. More time is needed to learn ICT } \\
\text { 2. Pressure to high-quality resources } \\
\text { 3. Additional pressure in a limited time } \\
\text { 4. Videos did not measurable } \\
\text { 5. Lack of practical sessions and discussion } \\
\text { 6. Loss of a social relationship } \\
\text { 7. Student competency development } \\
\text { 8. Not understand online assessments } \\
\text { 9. No constructive alignment }\end{array}$ \\
\hline $\begin{array}{l}\text { Opportunities }(\mathbf{O}) \\
\text { 1. New ICT-based resources } \\
\text { 2. Online collaboration }\end{array}$ & S-O strategy & W-O Strategy \\
\hline $\begin{array}{l}\text { 3. New insights and inspiration } \\
\text { 4. The importance of WFH } \\
\text { 5. Future remote work }\end{array}$ & $\begin{array}{l}\text { Increase Student and teacher Participation in } \\
\text { ICT Adaptation on ERL Based Learning }\end{array}$ & $\begin{array}{l}\text { Improving Quality Education Facilities and } \\
\text { Infrastructure }\end{array}$ \\
\hline $\begin{array}{l}\text { 6. Skills enhancement } \\
\text { 7. Future curriculum development } \\
\text { 8. Alternative exam methods, } \\
\text { 9. Free access to online resources }\end{array}$ & $\begin{array}{l}\text { Increasing High Concern for ICT Adaptation } \\
\text { on ERL Based Learning }\end{array}$ & $\begin{array}{l}\text { Modifying the emergency curriculum design } \\
\text { Establish public-private partnerships }\end{array}$ \\
\hline $\begin{array}{c}\text { Threats } \mathbf{( T )} \\
\text { 1. Convenience in learning } \\
\text { 2. Access to information and materials } \\
\text { 3. Interact with teachers } \\
\text { 4. Interact with classmates } \\
\text { 5. Study with other classmates } \\
\text { 6. Establish peer support } \\
\text { 7. Concepts taught } \\
\text { 8. Opportunity to discuss } \\
\text { 9. Not confident enough }\end{array}$ & $\begin{array}{c}\text { S-T strategy } \\
\text { Improving the quality of teachers in the field of } \\
\text { ICT } \\
\text { Improving social relationship-based teaching } \\
\text { Supervision of the ICT Adaptation on ERL } \\
\text { Based Learning }\end{array}$ & $\begin{array}{l}\text { Strengthening Internal-External Control in ICT } \\
\text { Adaptation on ERL Based Learning }\end{array}$ \\
\hline
\end{tabular}

\subsection{Discussion}

\subsubsection{Experiences of Students}

This study was conducted to investigate the experiences of students about ICT Adaptation in ERL Based Learning during the COVID-19 Pandemic in Aceh Province. The test results show that the level of student satisfaction in ERL learning obtained the average score of the four questions were in high level (3.52 on the 5-Likert scale) which means that students are satisfied with the ERL learning experience. The results of this study indicate that at the beginning of the COVID-19 outbreak, students experienced negative impacts due to distance learning, including mental health disorders, increased stress, high anxiety, and high depression. This finding is in agreement with [31][32][33]. However, after a year of the COVID-19 outbreak, students overall demonstrated a better learning experience, including higher levels of satisfaction, improved mental health, reduced depression, and anxiety. This finding is a positive indication of ICT Adaptation in ERL Based Learning during the COVID-19 Pandemic and is in accordance with the results of previous studies [31]. 


\subsubsection{Alternative strategies in the ICT adaptation on ERL-based learning}

Alternative Strategies in the ICT Adaptation on ERL Based Learning were formulated using a SWOT matrix analysis approach which produces several alternatives choices that can be useful for further policy-making in an effort to strengthen post-pandemic learning and support the "Merdeka Belajar" program launched by the government of the Republic of Indonesia. Alternative strategies that can be selected include:

a. Increase student and teacher participation in ICT adaptation on ERL-based learning. This strategy aims to provide encouragement to students and teachers to adapt to various environmental changes through increasing their involvement and participation in ICT adaptation on ERL Based Learning. This involvement and participation must be accompanied by efforts to increase learning motivation with existing ICT tools during the COVID-19 pandemic situation.

b. Increasing High Concern for ICT Adaptation on ERL-Based Learning. This strategy targets all parties to realize that education has a function to increase social solidarity between communities, especially in ICT adaptation so that everyone has a responsibility to use ICT as a learning tool that can contribute to overcoming the coronavirus outbreak so that education can become a pillar of concern. and universal social solidarity.

c. Improving Quality Education Facilities and Infrastructure. The implementation of ERL learning is one of the learning innovations from the 4.0 industrial revolution and educators and students are expected to be able to adapt and take advantage of ICT advances. Facilities and infrastructure are needed to provide quality educational services with the availability of technological instruments and infrastructure. ERL learning is inseparable from the means that support the learning process. The success of the information system application will work if other supporting facilities are complementary to each other, besides that the hardware that is also needed by education providers is a device or electronic device including desktop computers, laptops, smartphones, and tablets. To ensure the continuity of the learning process in an emergency, it is necessary to add internet quota, purchase/rent a mobile modem, and a school e-learning server.

d. Modifying the emergency curriculum design. Modifying the emergency curriculum design can be done with four innovations, namely curriculum structure, learning load, learning strategies, and assessment of learning outcomes. In the curriculum structure, teachers make changes by simplifying the lesson plans and basic competency indicators and shortening the duration of lesson hours. Likewise, the learning load is shorter and the number of subjects is only given two or three subjects per day. Learning strategies can be done in face-to-face and virtual classes. Face-to-face classes are carried out with shifts, rotations, full classes, home visits, and consultations. While virtual classroom learning can be done with zoom meetings, google classroom, google meet, e-learning madrasas, youtube streaming, video call whatsapp groups, or google sites. The implementation of the assessment of learning outcomes is carried out using google forms, quizzz, video calls, and voice notes.

e. Establish public-private partnerships. Establish partnership networks with various stakeholders and all elements of society is an absolute necessity. Cooperation and support from various development actors, coming from across sectors, businesses, educational institutions, civil society, and mass media, both at the central and regional levels, which are interwoven in the Penta helix collaboration based on the principles of equality, openness, and mutual benefit are very important in ICT adaptation to ERL-based learning.

f. Improving the quality of teachers in the field of ICT. The integration of ICT into the learning process is needed to develop teachers' higher-order thinking skills, develop skills in the field of ICT (ICT Literacy), and increase the effectiveness, efficiency, and attractiveness of the learning process. There are four competencies that must be mastered by teachers, namely pedagogic, professional, personality, and social competencies. Two of them are related to ICT, namely pedagogic competence and professional competence. The teacher's ICT competency improvement program is carried out in stages, namely level 1 ICT literacy, level 2 ICT implementation, level 3 ICT creation, and level 4 sharing (collaborative). Learning that aims to achieve ICT competence at every level is packaged in the form of technical guidance and the use of technology for e-learning.

g. Improving social relationship-based teaching. This strategy can be implemented with a structured approach, where teachers need to know and be able to apply several teaching principles in order to carry out their duties professionally, including (1) teachers must be able to arouse students' attention to the subject matter provided and be able to use various media and learning resources varied; (2) the teacher must be able to arouse the interest of students to be active in thinking and seek and find their own solutions to the problems they face; (3) the teacher must develop the attitude of students in fostering social relations, both among friends and with the community; and (4) teachers must investigate and explore the differences of individual participants in order to serve students according to their abilities.

h. Supervision of the ICT Adaptation on ERL Based Learning. Efforts that can be made to improve supervisory competence in order to present creative and innovative schools in the present context are optimizing the use of ICT. The use of ICT also provides the possibility of expanding access which reduces the digital divide and guarantees the success of education. Schools need to prepare school principals to take part in training/workshops to increase supervision competence in utilizing ICT, so that school principals have competence in planning, implementing, implementing follow-up, and preparing plans for implementing learning innovations through supervision by utilizing ICT.

i. Strengthening Internal-External Control in ICT Adaptation on ERL-Based Learning. The government needs to develop an education quality assurance system consisting of an internal quality assurance system and an external quality assurance system that covers all aspects of education by utilizing various resources in a sustainable manner. Control needs to be done so that teachers and students are better prepared to carry out ERL-based learning because it involves academic culture, which includes values, attitudes, knowledge, and skills, as well as the readiness of facilities and infrastructure related to information literacy. Ideally, a policy change regarding this learning paradigm is needed so that it can be used as a momentum for students to freely and critically seek knowledge and information digitally. Education 4.0 can be seen as a creative response in which humans utilize digital technology, open-source content, and global classrooms in the application of lifelong learning, flexible education systems, and personalized learning.

\section{Conclusion}

Education is currently in the midst of an unprecedented global pandemic crisis. The test results show that the level of student satisfaction in ICT Adaptation on ERL Based Learning obtained that students are satisfied with the ICT Adaptation on ERL Based Learning experience and no serious obstacles were found during the teaching-learning process during the COVID-19 pandemic except for inadequate interaction between students and teachers, as well as social interaction between students. Alternative strategies in the ICT adaptation on 
ERL-Based learning formulated using a SWOT matrix analysis approach have been presented with the hope that policymakers feel more confident in their decision-making.

Changes in the environment can occur suddenly so that academic responses can change at any time, besides that new threats and opportunities can emerge as the potential to create new resources and encourage more effective academic collaboration. It is suggested that a hybrid model, should be considered to encourage optimal learning. Alternative strategies that can be chosen include, increase student and teacher participation, increasing high concern for ICT adaptation, improving quality education facilities and infrastructure, modifying the emergency curriculum design, establishing public-private partnerships, improving the quality of teachers in the field of ICT, improving social relationship-based teaching, supervision of the ICT adaptation on ERL-based learning, strengthening internal-external control in ICT adaptation on ERL-based learning.

\section{Acknowledgement}

We are grateful to the many informants interviewed for this study. We also thank the Ministry of Education and Culture of the Republic of Indonesia and Universitas Malikussaleh.

\section{References}

[1] Zhang W, Wang Y, Yang L \& Wang C. (2020), Suspending classes without stopping learning: China's education emergency management policy in the COVID-19 outbreak. J. Risk Financ. Manag. 13, 55. [CrossRef]

[2] Worldometers. (2021). COVID-19 coronavirus global cases. n.d. Available online: https://www.worldometers.info/ (accessed on 1 May 2021)

[3] Dong E, Hongru D, \& Lauren G. (2020). COVID-19 in real time. Lancet Infect. Dis. 3099, 19-20. [CrossRef]

[4] Covid19.go.id (2021). Kasus covid per provinsi. Available online: https://covid19.go.id/p/berita/pasien-sembuh-terus-meningkat-mencapai1835061-orang (accessed on 1 May 2021).

[5] Statista. (2020). COVID-19's Staggering Impact On Global Education. Available online: https://www.statista.com/chart/21224/learners-impactedby-national-school-closures/ (accessed on 1 May 2021).

[6] UNESCO. (2020). Adverse consequences of school closures. Available online: https://en.unesco.org/covid19 (accessed on 1 May 2021).

[7] Wößmann L. (2003). Schooling resources, educational institutions and student performance: the international evidence. Oxf. Bull. Econ. Stat., 65, 117-170. [CrossRef]

[8] Furió D, Juan M.C, Seguí I \& Vivó R. (2015). Mobile learning vs. traditional classroom lessons: a comparative study. J. Comput. Assist. Learn., 31, 189-201. [CrossRef]

[9] Means B, Toyama Y, Murphy R, Bakia M \& Jones K. (2012). Evaluation of evidence-based practices in online learning: a meta-analysis and review of online learning studies. Available online: https://www2.ed.gov/rschstat/eval/tech/evidence-based-practices/finalreport.pdf (accessed on 1 May 2021).

[10] Jaume D, \& Willén A. (2019). The long-run effects of teacher strikes: evidence from Argentina. J. Labor Econ., 37, 1097-1139. [CrossRef]

[11] Hodges C, Moore S, Lockee B, Trust T \& Bond A. (2020). The difference between emergency remote teaching and online learning; EDUCAUSE Review: Louisville, CO, USA, Available online: https://er.educause.edu/articles/2020/3/the-difference-between-emergency-remote-teaching-andonline-learning (accessed on 1 May 2021).

[12] UNESCO. (2019). Migration, displacement \& education: building bridges, Not Walls. Available online: https://en.unesco.org/gemreport/report/2019/migration (accessed on 1 May 2021)

[13] Miralles-Martínez P, Gómez-Carrasco C.J \& Sánchez-Ibañez R. (2014). Ask me questions and I will tell you what they assess and teach. an analysis of social sciences exams in the 5th and 6th grade of primary school. Aula Abierta, 42, 83-89. [CrossRef]

[14] Ortega-Sánchez D \& Gómez-Trigueros I.M. (2019). Massive open online courses in the initial training of social science teachers: experiences, methodological conceptions, and technological use for sustainable development. Sustainability 2019, 11, 578. [CrossRef]

[15] Erica Rosenfeld Halverson, Amanda Farrar, Kathy Sliter, \& Nathan Wheeler. (2020). Whoopensocker fights the zombie apocalypse: supporting teachers with digital arts-based curriculum. Available online: https://www.learntechlib.org/p/216903/. (accessed on 1 May 2021).

[16] Barchas-Lichtenstein J, Brucker J.L, Nock K, Gupta R \& Flinner K. (2020). education in the pandemic \& the potential for computational thinking. Knology Publication \#EDU.051.602.01. Knology.

[17] Morgan DL. (2007). Paradigms lost and pragmatism regained, Journal of Mixed Methods Research, Vol. 1, No. 1, pp.48-76.

[18] Easterby-Smith M, Thorpe R \& Lowe, A. (1991) Management Research: An Introduction, Sage Publications, London.

[19] Helms MM \& Nixon J. (2010). Exploring SWOT analysis-where are we now? A review of academic research from the last decade. $J$ Strateg Manag 3:215-251.

[20] Teoli D \& An J. (2019). SWOT Analysis. NCBI Internet Bookshelf. Treasure Island, FL: StatPearls Publishing. Available online:https://www.ncbi.nlm.nih.gov/pubmed/30725987 (accessed on 1 May 2021).

[21] Sit JW, Chung JW, Chow MC \& Wong TK. (2005). Experiences of online learning: Students' perspective. Nurse Educ. Today, 25, 140-147. [CrossRef]

[22] Zikmund WG. (2003) Business research methods, Thomson/South-Western, Cincinnati.

[23] Davis D. (2005) Business research for decision making, Thomson South-Western, Mason.

[24] Davis D \& Cosenza, R.M. (1993) Business research for decision making, Wadsworth Publishing, Belmont.

[25] Aragon-Sanchez A \& Sanchez-Marin, G. (2005). Strategic orientation, management characteristics, and performance: a study of Spanish SMEs, Journal of Small Business Management, Vol. 43, No. 3, pp.287-308.

[26] Homburg C \& Jensen, O. (2007). The thought worlds of marketing and sales: which differences make a difference?, Journal of Marketing, Vol. 71, No. 3, pp.124-142.

[27] Hair JF, Black WC, Babin BJ \& Anderson, R.E. (2010). Multivariate data analysis, Pearson Education Inc., Pearson, NJ.

[28] Bagozzi RP \& Yi Y. (1988). On the evaluation of structure equations models, Academic of Marketing Science, Vol. 16, No. 1, pp.76-94.

[29] Tabachnick BG \& Fidell LS. (2001). Using multivariate statistics, Allyn and Bacon, Needham Heights.

[30] Manning M \& Munro D. (2007). The survey researcher's SPSS cookbook, Pearson Education Australia, Sydney.

[31] Gao J, Zheng P, Jia Y, Chen H, Mao Y, Chen S, Wang Y, Fu H \& Dai J. (2020). Mental health problems and social media exposure during COVID-19 outbreak. PLOS ONE 15, e0231924.

[32] Liang L, Ren H, Cao R, Hu Y, Qin Z, Li C \& Mei S. (2020). The effect of COVID-19 on youth mental health. Psychiatr. Q. 91, 841-852. [CrossRef] [PubMed]

[33] Brown SM, Doom JR, Lechuga-Peña S, Watamura SE \& Koppels T. (2020). Stress and parenting during the global COVID-19 pandemic. Child Abus. Negl. 110, 104699. [CrossRef] 